\title{
Anti-Toxoplasma gondii antibodies in mammals, birds and reptiles at the zoological-botanical park in João Pessoa, Paraíba, Brazil
}

\author{
Anticorpos anti-Toxoplasma gondii em mamíferos, aves e \\ répteis no parque zoobotânico em João Pessoa, Paraíba, Brasil
}

\author{
Thais Ferreira Feitosa ${ }^{*}$, Arthur Willian de Lima Brasil ${ }^{2}$, Roberta Nunes Parentoni², Vinícius Longo \\ Ribeiro Vilela ${ }^{1}$, Thiago Ferreira Lopes Nety ${ }^{3}$, Hilda Fátima de Jesus Pena4
}

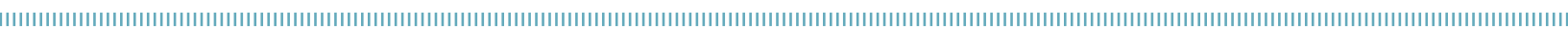

\begin{abstract}
The purpose of this study was to verify the occurrence of anti-Toxoplasma gondii antibodies in 51 wild animals at the Arruda Câmara Zoological-Botanical Park in João Pessoa, $\mathrm{PB}$, Brazil. Blood samples from different bird, mammal and reptile species were analyzed using the Modified Agglutination Test (MAT) with a cut-off point of 1:25. Anti-T. gondii antibodies were detected in $62.4 \%$ of the 51 tested animals. The following frequencies were found: $68.9 \%(20 / 29)$ in mammals, $80 \%$ (8/10) in birds, and $33.3 \%(4 / 12)$ in reptiles. This paper reports for the first time the occurrence of anti- $T$. gondii antibodies in birds of the species Pionites leucogaster (caíque), Anodorhynchus hyacinthinus (hyacinth macaw), Pavo cristatus (Indian peafowl), Urubitinga urubitinga (Brazilian eagle), and Buteo melanoleucus (black-and-white hawkeagle). Reptiles of the species Caiman crocodilus (spectacled caiman), Chelonoidis carbonaria (red-footed tortoise) and Paleosuchus palpebrosus (Cuvier's dwarf caiman) were seropositive for T. gondii, although the significance of the presence of these anti-T. gondii antibodies in this group of animals requires a more in-depth study. We conclude that the frequency of antibodies found in the animals of this zoo is high and that the prophylactic measures that aim to diminish the environmental contamination by oocysts are necessary.
\end{abstract}

KEYWORDS: modified agglutination test; seroprevalence; Toxoplasma gondii; zoo animals; zoonosis.
RESUMO: Este trabalho teve como objetivo verificar a ocorrência de anticorpos anti-Toxoplasma gondii em 51 animais silvestres mantidos no Parque Zoobotânico Arruda Câmara, João Pessoa, Brasil. Para isso, foram avaliadas amostras sanguíneas de diferentes espécies de aves, mamíferos e répteis por meio do Teste de Aglutinação Modificado (MAT) com ponto de corte de 1:25. Dos 51 animais testados, $62,4 \%$ apresentaram anticorpos anti- $T$. gondii. Nos mamíferos, a frequência encontrada foi de 68,9\% (20/29), em aves foi de $80 \%(8 / 10)$ e em répteis de 33,3\% (4/12). Pela primeira vez é relatada a ocorrência de anticorpos anti- $T$. gondii em aves das espécies Pionites leucogaster (marianinha-de-cabeça-amarela), Anodorhynchus hyacinthinus (arara-azul-grande), Pavo cristatus (pavão), Urubitinga urubitinga (gaviáo-preto) e Buteo melanoleucus (águia-chilena). Répteis das espécies Caiman crocodilus (jacaretinga), Chelonoidis carbonaria (jabuti) e Paleosuchus palpebrosus (jacaré-anão) foram soropositivos para T. gondii, embora o significado da presença desses anticorpos anti-T. gondii precise ser mais bem estudado nesse grupo de animais. Conclui-se que é alta a frequência de anticorpos encontrados nos animais do zoológico estudado e que medidas profiláticas que visem diminuir a contaminação ambiental por oocistos são necessárias.

PALAVRAS-CHAVE: animais de zoológico; soroprevalência; teste de aglutinação modificada; Toxoplasma gondii; zoonoses. 
Toxoplasma gondii is an important protozoan parasite that affects humans and domestic and wild animals (DUBEY; BEATTIE, 1988; MINERVINO et al., 2010). The main problem this parasite causes in humans is reported in pregnant women, in whom the infection during pregnancy can cause irreversible damage to the fetus and may even lead to miscarriage. In farm animals, the main damage caused by $T$. gondii is abortion and economic losses (TSUTSUI et al., 2005).

T. gondii infections in zoos are extremely important, since many animals living in captivity die without exhibiting characteristic symptoms, and also due to the risk of environmental contamination, since infected felids can eliminate millions of oocysts, thus representing a source of infection for the other animals and for visitors (CAMPS et al., 2008). Acute toxoplasmosis can kill wild life species such as Australian marsupials, New World monkeys, lemurs, cougars, canaries, antelopes and finches, among others (SEDLÁK; BÁRTOVÁ, 2006; CAMPS et al., 2008; DUBEY; BEATTIE, 1988).

Studies in Brazil and around the world have performed serological surveys of $T$. gondii in several animal species living in zoos (SILVA et al., 2001; PIMENTEL et al., 2009; CAMPS et al., 2008; MINERVINO et al., 2010). However, few studies have focused on $T$. gondii in wild birds of the Brazilian fauna, and it holds even truer in the case of reptiles, for which the literature is devoid of reports describing seropositive animals.

The purpose of this study was therefore to investigate the occurrence of anti-T. gondii antibodies in mammals, birds and reptiles at the Arruda Câmara Zoological-Botanical Park, in the state of Paraíba (7011'40.99”S, 34087'61.99”W), in northeastern Brazil (Fig. 1).

This research was approved by the Ethic Committee on Research of Universidade Federal de Campina Grande, under the protocol number $178 \mathrm{~b}-2014$.

Blood samples of varying volumes were collected from 29 mammals, 10 birds and 12 reptiles, using a disposable syringe and needle. The samples were drawn by puncture of the venous occipitals or the jugular, ulnar, cephalic and femoral veins, according to the animal species. The blood was centrifuged to obtain serum and then stored at $-20^{\circ} \mathrm{C}$ until processing. None of the animals was sick when the blood was collected.

Sera from the animals were tested for anti-T. gondii antibodies at the Faculty of Veterinary Medicine and Animal Science of the Universidade de São Paulo, using the Modified Agglutination Test (MAT) with tachyzoites inactivated, formalin
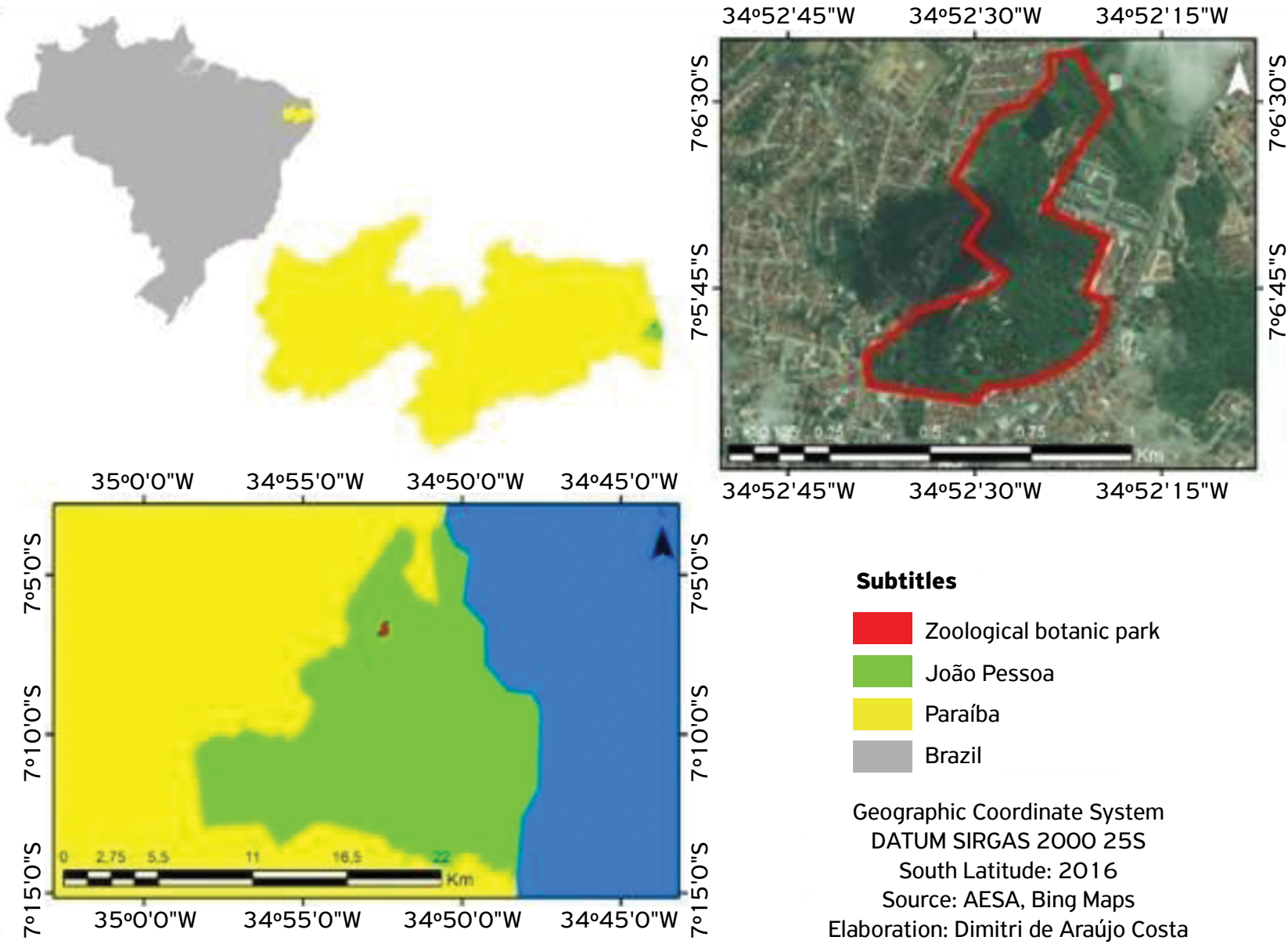

Source: COSTA et al. (2017).

Elaboration: Dimitri de Araújo Costa

Figure 1. Map of the Arruda Câmara Zoological-Botanical Park localization, municipality of João Pessoa (PB), Brazil. 
and 2-mercaptoethanolas described by DUBEY; DESMONTS (1987). Titers of 1:25 or higher were considered indicative of exposure to T. gondii. Each battery of tests included positive and negative controls.

Of the 51 tested animals, $62.4 \%$ presented anti- $T$. gondii antibodies. In the mammals, antibodies were found in $68.9 \%$ (20/29) of the tested animals, with titers ranging from 25 to 6,400 (Table 1). It was observed that all animals of the species Sapajus libidinosus, Nasuanasua, Coendu sp., Rattus rattus, Galictis vittata and Tayassu tajacu presented antibodies positive for T. gondii.

The frequency of antibodies found in the birds was $80 \%$ $(8 / 10)$, with titers varying from 25 to 3,200 (Table 1). Only two species of birds were not positive for T. gondii: Ara chloropterus and Polyborus plancus. For the first time the occurrence of anti-T. gondii antibodies in birds of the species Pionites leucogaster (caíque), Anodorhynchus hyacinthinus (hyacinth macaw), Pavo

Table 1. Presence of anti-Toxoplasma gondii antibodies (MAT $\geq 25$ ) in wild captive animals at the Arruda Câmara ZoologicalBotanical Park in João Pessoa, northeastern Brazil.

\begin{tabular}{|c|c|c|}
\hline Animals species & No. examined/positive(\%) & Titer range \\
\hline \multicolumn{3}{|l|}{ Mammals } \\
\hline Black rat (Rattus rattus) & $1 / 1(100 \%)$ & 400 \\
\hline Black-striped capuchin (Sapajus libidinosus) & $5 / 5(100 \%)$ & $200-6,400$ \\
\hline Greater grison (Galictis vittata) & $2 / 2(100 \%)$ & $50-200$ \\
\hline Hoary fox (Lycalopex vetulus) & $2 / 0(0 \%)$ & - \\
\hline Coati (Nasua nasua) & $5 / 5(100 \%)$ & $100-800$ \\
\hline Collared peccary (Tayassu tajacu) & $1 / 1(100 \%)$ & 400 \\
\hline Ocelot (Leopardus pardalis) & $5 / 3(60 \%)$ & 1,600 \\
\hline Oncilla (Leopardus tigrinus) & $5 / 2(40 \%)$ & $200-1,600$ \\
\hline Porcupine (Coendou sp.) & $1 / 1(100 \%)$ & 25 \\
\hline Squirrel monkey (Saimiri sciureus) & $1 / 0(0 \%)$ & - \\
\hline Tayra (Eira Barbara) & $1 / 0(0 \%)$ & - \\
\hline \multicolumn{3}{|l|}{ Birds } \\
\hline Black-and-white hawk-eagle (Buteo melanoleucus) & $1 / 1(100 \%)$ & 25 \\
\hline Brazilian eagle (Urubitinga urubitinga) & $1 / 1(100 \%)$ & 25 \\
\hline Caique (Pionites leucogaster) & $1 / 1(100 \%)$ & 100 \\
\hline Hyacinth macaw (Anodorhynchus hyacinthinus) & $1 / 1(100 \%)$ & 50 \\
\hline Indian peafowl (Pavo cristatus) & $3 / 3(100 \%)$ & $25-3,200$ \\
\hline Red-and-green macaw (Ara chloropterus) & $1 / 0(0 \%)$ & - \\
\hline Southern crested caracara (Polyborus plancus) & $1 / 0(0 \%)$ & - \\
\hline White-browed guan (Penelope jacucaca) & $1 / 1(100 \%)$ & 400 \\
\hline \multicolumn{3}{|l|}{ Reptiles } \\
\hline Amazon tree boa (Corallus hortulanus) & $1 / 0(0 \%)$ & - \\
\hline Argentine black and white tegu (Tupinambis merianae) & $1 / 0(0 \%)$ & - \\
\hline Broad-snouted caiman (Caiman latirostris) & $1 / 0(0 \%)$ & - \\
\hline Burmese python (Python molurus) & $1 / 0(0 \%)$ & - \\
\hline Cuvier's dwarf caiman (Paleosuchus palpebrosus) & $1 / 1(100 \%)$ & 800 \\
\hline Gold tegu (Tupinambis teguixin) & $1 / 0(0 \%)$ & - \\
\hline Red-footed tortoise (Chelonoidis carbonaria) & $3 / 2(66 \%)$ & 100 \\
\hline Spectacled caiman (Caiman crocodilus) & $1 / 1(100 \%)$ & 50 \\
\hline Toad head turtle (Bufocephala vanderhaegei) & $1 / 0(0 \%)$ & - \\
\hline Yellow-footed tortoise (Chelonoidis denticulata) & $1 / 0(0 \%)$ & - \\
\hline Total & $51 / 32(62.7 \%)$ & $25-3,200$ \\
\hline
\end{tabular}


cristatus (Indian peafowl), Urubitinga urubitinga (Brazilian eagle), and Buteo melanoleucus (black-and-white hawk-eagle) is reported.

Antibodies were found in $33.3 \%$ (4/12) of the tested reptiles, with titers varying from 50 to 800 (Table 1). Caiman crocodilus, Chelonoidis carbonaria and Paleosuchus palpebrosus were the three species of reptiles that showed positive antibody titers to T. gondii.

The frequency of antibodies found in zoo animals is variable and depends on numerous factors intrinsic to the management and administration of each zoo. In this study, we observed the frequency of $68.9 \%$ of positive mammals, which is similar to that described by PIMENTEL et al. (2009), who reported that $53.1 \%(17 / 32)$ of the animals tested at the Aracaju zoo were positive. On the other hand, this frequency is considered high compared to that one reported by MINERVINO et al. (2010). They analyzed a six times more mammals and found that $33 \%(61 / 184)$ tested positive in various zoos in the north and northeast of Brazil.

In this study, the presence of positive felines indicates that these animals probably eliminated oocysts in their feces, contaminating the environment. These animals may have become infected through their food, since it is a zoo practice a form of environmental enrichment by feeding the felines with live chickens, whose tissues may contain bradyzoites, that can infect the cats. Carnivorism is considered the most efficient route of infection of cats (BOWMAN, 2010). Currently, a safe option to avoid contamination of animals through tissue cysts is to freeze the meat before offering it (KIJLSTRA; JONGERT, 2008). Moreover, the zoo has no control over synanthropic animals, and the presence of domestic cats is frequent, which may lead to environmental contamination and thus infection of wild felines.

The high frequency of positive monkeys found in this serological survey can be attributed to these animals' change of behavior in captivity, because in this situation they spend much of the day on the floor of their enclosures, favoring greater contact with oocysts (SILVA, 2006). Furthermore, the animals are fed with raw meat, which may serve as a source of infection. DUBEY; BEATTIE (1988) described the Saimiri sciureus is a species of monkey highly susceptible to $T$. gondii, but the only specimen tested in this study was negative. In general, the number of T. gondii positive monkeys is high. In a study at the Wild Animal Screening Center (CETAS) in Seropédica, Rio de Janeiro, PIRES et al. (2012) found that 16 of the 21 Sapajus sp. examined were positive for anti-T. gondii antibodies. PIMENTEL et al. (2009) also reported that a high frequency of $75 \%$ of Sapajus xanthosternos tested positive.

In this study, we observed a frequency of $80 \%$ of positive birds. It is considered high when compared with other studies, such as that by MINERVINO et al. (2010), who found no animal seropositive for T. gondii in 19 wild birds, and ALVARADO-ESQUIVEL et al. (2011), who analyzed 633 wild birds of free life and found a prevalence of $2.6 \%$ of birds analyzed in metropolitan and rural area of Durango State, Mexico. The serological study at the Arruda Câmara Zoological-Botanical Park, in João Pessoa, led to the first description of birds of the species Pionites leucogaster, Anodorhynchus hyacinthinus, Pavo cristatus, Urubitinga urubitinga and Buteo melanoleucus positive for T. gondii. Recently, TIAN et al. (2012) gave the first description of a species of the genus Pavo positive for $T$. gondii, reporting seropositive animals of the species $P$. muticus.

In this epidemiological survey, reptiles (Caiman crocodilus, Chelonoidis carbonaria and Paleosuchus palpebrosus) seropositive for T.gondii were found, with titers ranging from 50 to 800. The caimans at the Arruda Câmara Zoological-Botanical Park, which lived in an artificial lake, were fed with raw beef and live chickens. The snakes, which were housed in individual cages, were fed not only with raw beef and chickens, but also with newborn mice. Serological surveys of $T$. gondii in reptiles are scanty, probably because of the difficulty of drawing blood from these animals, since much experience is required to avoid impairing their health and that of the handlers during the collection.

FERREIRA et al. (2012) also found seropositive reptiles in a survey of caimans of the species Melanosuchu sniger and Caiman crocodilus in the Araguaia region of Brazil, reporting $7.7 \%(8 / 104)$ of animals positive in MAT and also in the western blotting technique. The significance of the presence of anti-T. gondii antibodies in reptiles needs to be better investigated, since LAINSON et al. (1997) suggested that poikilothermic animals have natural immunity to infection, and several authors state that $T$. gondii is able to maintain its infection only in warm-blooded animals (DUBEY, 2004; TENTER et al., 2000). According to FERREIRA et al. (2012), the paradigm that the parasite is able to infect only warmblooded animals may have changed, in view of the serological evidence of infection by $T$. gondii. However, this hypothesis could only be confirmed by isolating the parasite from the tissues of poikilothermic animals.

The animals in the zoo of this study showed a high frequency of anti-T. gondii antibodies. Prophylactic measures zoo aimed at reducing the infection of these animals by $T$. gondii should be adopted, because, although most of them did not present clinical signs, some of these animals are highly susceptible and may die from toxoplasmosis, which is a serious problem for zoos, one of whose objectives is species preservation. Do not feed animals with fresh meat, freezing storage before meat consumption e controlling the access of synanthropic animals and domestic cats to zoo environments are important measures to prevent toxoplasmosis in zoo animals, although it is still a challenge for zoos. 


\section{REFERENCES}

ALVARADO-ESQUIVEL, C.; RAJENDRAN, C.; FERREIRA, L.R.; KWOK, O.C.; CHOUDHARY, S.; ALVARADO-ESQUIVEL, D.; RODRÍGUEZPEÑA, S.; VILLENA, I.; DUBEY, J.P. Prevalence of Toxoplasma gondii infection in wild birds in Durango, Mexico. The Journal of Parasitology, v.97, p.809-812, 2011.

BOWMAN, D.D. (Ed.). Georgis: Parasitologia Veterinária. Rio de Janeiro: Elsevier, 2010. 432p.

CAMPS, S.; DUBEY, J.P.; SAVILLE, W.J.A. Seroepidemiology of Toxoplasma gondii in zoo animals in selected zoos in the Midwestern United States. The Journal of Parasitology, v.94, p.648-653, 2008.

COSTA, D.A.; MARINHO, R.S.A.; SOARES, H.K.L.; SANTOS, S.S.; FURTADO, G.D. Análise do comportamento dos felinos do parque zoobotânico arruda câmara ("bica”), João Pessoa, Paraíba, Brasil. Educação Ambiental em Ação, v.59, p. 1-5, 2017.

DUBEY, J.P. Toxoplasmosis: a waterbone zoonosis. Veterinary Parasitology, v.126, p.57-72, 2004.

DUBEY, J.P.; BEATTIE, P. (Eds.). Toxoplasmosis of Animals and Man. Florida: Boca Raton, 1988. 220p.

DUBEY, J.P.; DESMONTS, G. Serological responses of equids fed Toxoplasma gondii oocysts. Equine Veterinary Journal, v.19, p.337-339, 1987.

FERREIRA, F.B.; SANTIAGO, F.M.; MACÊDO JUNIOR, A.G.; SILVA, M.V.; FERREIRA JR., A.; VITALIANO, S.N.; GENNARI, S.M.; OLIVEIRA SILVA, D.A.; MINEO, J.R.; SANTOS, A.L.Q.; MINEO, T.W.P. Evaluation of seroreactivity to Toxoplasma gondii in alligators. In: REUNIÃO ANUAL DA SOCIEDADE BRASILEIRA DE PROTOZOOLOGIA, 28., 2012, Caxambu. Anais... Caxambu: SBPZ, 2012. Available from: <https:// sbpz.org.br/wp-content/uploads/2015/12/12-EP\%20-\%2Opg\%20 151\%20ate\%20156_2012.pdf>. Accessed on: Aug. 272015.

KIJLSTRA, A.; JONGERT, E. Control of the risk of humantoxoplasmosis transmitted by meat.International Journal forParasitology, v.38, p. 1359-1370, 2008

LAINSON, R.; LEÃO, R.N.Q.; CRESCENTE, J.A.B. Toxoplasmose. In: LEÃO, R.N.Q. (Ed.). Doenças infecciosas e parasitárias: enfoque amazônico. Belém: CEJUP, 1997. Chap.18, p.671-683.
MINERVINO, A.H.H.; SOARES, H.S.; BARRÊTO JÚNIOR, R.A.; NEVES, K.A.L.; PENA, H.F.J.; ORTOLANI, E.L.; DUBEY, J.P.; GENNARI, S.M. Seroprevalence of Toxoplasma gondii antibodies in captive wild mammals and birds in Brazil. Journal of Zoo and Wild Life Medicine, v.41, p.572-574, 2010.

PIMENTEL, J.S.; GENNARI, M.S.; DUBEY, J.P.; MARVULO, M.F.V.; VASCONCELLOS, A.S.; MORAIS, Z.M.; SILVA, J.C.R.; EVÊNCIO NETO, J. Inquérito sorológico para toxoplasmose e leptospirose em mamíferos selvagens neotropicais do zoológico de Aracaju, Sergipe. Pesquisa Veterinária Brasileira, v.29, p.1009-1014, 2009.

PIRES, J.S.; RIBEIRO, C.T.; CARVALHO FILHO, P.R.; PISSINATTI, A.; FLAUSINO, W.; LOPES, C.W.G. Infection by Toxoplasma gondii in Neotropical non-human primates. Pesquisa Veterinária Brasileira, v.32, p.1041-1044, 2012.

SEDLÁK, K.; BÁRTOVÁ, E. Seroprevalences of antibodies to Neospora caninum and Toxoplasma gondii in zoo animals. Veterinary Parasitology, v.136, p.223-231, 2006.

SILVA, J.C.R. Toxoplasmose. In: CUBAS, Z.S.; SILVA, J.C.R.; CATÃO-DIAS, J.L. (Eds.). Tratado de Animais Selvagens: Medicina Veterinária. São Paulo: Roca, 2006. Chap.26, p.768-784.

SILVA, J.C.R.; OGASSAWARA, S.; ADANIA, C.H.; FERREIRA, F.; GENNARI, S.M.; DUBEY, J.P.; FERREIRA-NETO, J.S. Seroprevalence of Toxoplasma gondii in captive Neotropical felids from Brazil. Veterinary Parasitology, v. 102, p.217-224, 2001.

TENTER, A.M.; HECKEROTH, A.R.; WEISS, L.M. Toxoplasma gondii: from animals to humans. International Journal of Parasitology, v.30, p.1217-1258, 2000 .

TIAN, Y.; DAI, F.; HUANG, S.; DENG, Z.; DUAN, G.; ZHOU, D.; YANG, J.-F.; WENG, Y.-B.; ZHU, X.-Q.; ZOU, F.C. First report of Toxoplasma gondii seroprevalence in peafowl in Yunnan Province, Southwestern. Parasites and Vectors, v.5, p.205-208, 2012.

TSUTSUI, V.S.; NAVARRO, I.T.; FREIRE, R.L.; FREITAS, J.C.; PRUDENCIO, L.B.; DELBEM, A.C.B.; MARANA, E.R.M. Soroepidemiologia e fatores associados à transmissão do Toxoplasma gondii em suínos do norte do Paraná, Brasil. Archives of Veterinary Science, v.8, p.27-34, 2005. 